\title{
Rhizopus spp Promoting and Inducing Late Blight (Phytophthora infestans) Resistance in Solanum lycopersicum L.
}

\author{
C. Agbor $^{1}$, Fotso $^{2}$, A. C. Djueani ${ }^{3}$, R. F. Muyang ${ }^{2}$ and H. D. Mbouobda ${ }^{1,2^{*}}$ \\ ${ }^{1}$ Department of Biochemistry, Faculty of Sciences, The University of Bamenda, P.O.Box-39, \\ Bamenda, Cameroon. \\ ${ }^{2}$ Department of Biology, Faculty of Sciences, The University of Bamenda, P.O.Box-39, Bamenda, \\ Cameroon. \\ ${ }^{3}$ Department of Plant Biology, Faculty of Sciences, University of Yaoundé I, P.O.Box- 812 Yaoundé, \\ Cameroon.
}

\section{Authors' contributions}

This work was carried out in collaboration among all authors. Authors F, RFM and HDM designed the study, performed the statistical analysis and wrote the protocol. Authors CA and HDM wrote the first draft of the manuscript. Authors ACD and HDM managed the analyses of the study. Authors CA and $A C D$ managed the literature searches. All authors read and approved the final manuscript.

Article Information

DOI: $10.9734 / A R R B / 2021 / v 36 i 230338$

Editor(s):

(1) Dr. Amit Kesarwani, G. B. Pant University of Agriculture and Technology, India.

(2) Dr. Paola Angelini, University of Perugia, Italy.

(3) Dr. Msafiri Yusuph Mkonda, Sokoine University of Agriculture, Tanzania.

Reviewers:

(1) Reem Ibrahim Hasan, School of Computing N28A, Malaysia and Public University in Baghdad, Iraq.

(2) Jorge Carrasco Fernández, Chile.

(3) Seweta Srivastava, Lovely Professional University, India. Complete Peer review History: http://www.sdiarticle4.com/review-history/65585

Original research Article

Received 21 December 2020

Accepted 27 February 2021

Published 19 March 2021

\section{ABSTRACT}

Tomato (Solanum lycopersicum L) which is highly consumed by humans, suffer severe attacks of various pathogens. Among these pathogens, Phytophthora infestans is the most prominent causing a devastating tomato disease called late blight. This study was aimed at evaluating the protective effects of Rhizopus spp on tomato plant growth upon infection with $P$. infestans. The work was partition into two phases: phase 1 delt with the effect of Rhizopus spp on tomato growth parameters while phase 2 was on the protective effects of Rhizopus spp against late blight in tomato and its attributes on biochemical parameters. In phase 1 seedlings were raised and divided 
into five groups of six plants each. Group I was the control while Groups II to V were treated with Rhizopus spp (2.5; $5.0 ; 7.5$ and $10.0 \mathrm{mg} / \mathrm{ml}$ respectively) for 25 days. After every 5 days' plants were treated and on each day of treatment, growth parameters (number of leaves and height) and chlorophyll contents measured. On day 25, samples were collected for biochemical analysis (flavonoids, phenolic content, total protein, vitamin C, catalase (CAT), reduced glutathione (GSH)). In phase 2, Rhizopus at $5 \mathrm{mg} / \mathrm{ml}$ obtained as best results in phase one was used. Raised seedlings were divided into four groups: Group 1 was healthy $(\mathrm{H})$, Group 2 of plants infected with $P$. infestans (50 mg/ml) (I), Group 3 of plants stimulated with Rhizopus spp $(5.0 \mathrm{mg} / \mathrm{ml})$ (St), and Group 4 of plants inoculated with $P$. infestans after stimulation with Rhizopus spp $(\mathrm{St}+\mathrm{I})$ for 7 days. Every two days, diseases incidence and severity were recorded and after $10^{\text {th }}$ days samples were collected for biochemical (total protein, CAT and GSH) analysis. As results, Rhizopus spp inoculation induced an increase in the number of leaves, plant height and chlorophyll contents compared to the control group with plants of group II (Rhizopus spp $5.0 \mathrm{mg} / \mathrm{ml}$ ) having the best result. A significant increase $(p<0.05)$ in flavonoid, phenolic content, reduced glutathione level and catalase activity were recorded. Another significant increase $(p<0.05)$ in disease incidence and severity in plants treated with the pathogen when compared to the control. Co-inoculation of plants with Rhizopus spp and $P$. infestans significantly decreased disease incidence and severity. Also a significant decrease in GSH level and CAT activity were noticed. Co-inoculation of plants with Rhizopus spp and $P$. infestans significantly increased $(p<0.05)$ GSH level and CAT activity when compared to the control group. In conclusion Rhizopus spp instigate plant growth and induce disease resistance in tomato upon infection with $P$. infestans causing late blight.

Keywords: P. infestans; Rhizopus spp; tomato; growth; late blight.

\section{INTRODUCTION}

Tomato (Solanum lycopersicum L.) belonging to the Solanaceae family is one of the most widespread vegetables worldwide, with more than 160 million tons produced alone in 2013 [1]. Tomato is also widely grown in Cameroon, especially in the North West Region where he serves as a source of food and income to the local population. They are highly consumed as fresh fruits or processed products, due to their nutritional and beneficial properties to human health [2]. This crops, however, suffers attacks and damages from several pathogens such as viruses, bacteria, fungi, nematodes and abiotic factors which cause substantial production losses [3]. Among these diseases, late blight caused by Phytophthora infestans is the most prominent disease affecting tomatoes leading to decreased and fluctuation in production [4]. In Tanzania and Morogoro, studies have shown that yield loss of tomato as a result of late blight disease infection is estimated to be up to $46 \%$ [5] while in Cameroon mean yield loss attributable to late blight damage is estimated to be as high as $100 \%$ [6]. In the world, late blight is one of the most devastating tomato disease which requires high chemical input for disease control [7]. Upon infection, most infected seedlings die and those that survive are stunted, have yellowish leaves and do not flower. $P$. infestans is a pathogen which occurs throughout most tomato growing areas and causes severe crop damage to both greenhouse and field depending on the varieties of tomato cultivars and the environmental conditions [8]. During favourable conditions (high humidity and temperature), late blight can destroy the entire tomato crop production [4]. The pathogen has different mechanisms of survival and two infection phases in its life cycle and the life cycle is divided into sexual and asexual cycles [9]. The asexual life cycle of $P$. infestans is characterized by alternating phases of hyphal growth, sporulation, sporangia germination (either through zoospore release or direct germination that is through germ tube emergence from the sporangium) and the reestablishment of hyphal growth while the sexual reproductive cycle occurs only once annually when two mating types (referred to as type $A 1$ and type A2) interact [10].

In order to combat and counteract the effects of this pathogen, fungicides are broadly applied to tomato plants in order to prevent severe epidemics and pathogen's invasion, inhibit growth as well as destroying reproduction stages of pathogen [11].

The use of fungicides and the development of resistant cultivars are important alternatives for pathogen management and control, but these chemicals however are harmful to humans, microorganisms, environment and yet no highly 
resistant cultivars [4]. Although the use of resistant cultivars can provide greater degree of disease resistance, the emergence of new races of the pathogens that overcome resistance remains a problem [8].

Today, one goal of modern agriculture is the production of safe food through sustainable and eco-friendly practices. So these involved a cutback in the use of chemicals in the fields to reduce potential environmental damage [12]. In this regards, novel eco-friendly and safe strategies or practices have been explored for the management of plant diseases [8]. Thus, biological agents constitute an excellent alternative to replace chemicals for growth improvement or pest control by activating plant immune system to boost plant resistance [11] One of such biological agents which are ecofriendly and safe to promote sustainable development that have been explored for the growth and management of plant diseases is the use of plant growth-promoting fungi (PGPFs).

There exist a number of plant growth-promoting fungi (PGPFs) in rhizosphere soils (such as species of the genera Trichoderma, Penicillium, Fusarium, and Phoma) which have the ability to promote growth and stimulate plant immune response upon invaders attack and are seen as one of the safest mode for induced systemic resistance (ISR) and growth promotion in crop plants [13]. PGPFs such as fungi are considered to have advantageous effects on plant health and nutrient uptake [14]. Several mode of actions (direct and indirect mechanisms) have been described on how PGPFs influence plant growth and fitness [12]. PGPFs may make use of one of the several mechanisms to promote plant growth and resistance like production of phytohormones, solubilization of minerals, nitrogen fixation, antibiosis, production of lytic enzymes and antagonism to phytopathogens $[15,16]$. Several PGPF isolates have the capacity to solubilized phosphates (phosphate solubilizing fungi), minerals, and micronutrients which play an important role in plant growth promotion [17]. Phosphorous $(P)$ is an essential or vital macronutrient for plant growth and it plays an important role in energy transfer reactions, flower formation, fruit production, stimulates root development, respiration, photosynthesis and resistance to plant diseases [18]. One of such fungal which have the ability to solubilized phosphate is the Rhizopus species. Rhizopus $s p p$ is a saprotrophic filamentous fungi of the genus Rhizopus [19]. Studies have shown that
Rhizopus spp are also among the several PGPF isolates which are known for solubilization of phosphates hence the name phosphate solubilizing fungi which contribute an important role in plant growth promotion.

Therefore, this study was aimed at developing environmentally friendly and safe protection methods to minimize tomato disease (late blight) caused by $P$. infestans while promoting plant growth in order to reduce the excessive use of hazardous chemicals. With the above views, the objective of this present study was aimed to evaluate the ability of Rhizopus spp to promote growth and mediate tomato plant resistance against blight caused by Phytophthora infestans.

\section{MATERIALS AND METHODS}

\subsection{Description of the Experimental Site}

The field experiment was conducted at Bambili, Mezam Division, and North West Region of Cameroon. The investigation was conducted from February to June 2020. The location site lies between $5^{\circ} 59^{\prime} 0^{\prime \prime}$ North and $10^{\circ} 15^{\prime} 0^{\prime \prime}$ East at an altitude of 2273 meter above the mean sea level. The laboratory experiment was conducted in the HTTC laboratory Department of Biology University of Bamenda.

\subsection{Preparation of Media}

PDA media were used during the course of investigation and the preparation of media was done following the Mbouobda method [20]. The prepared media were sterilized at $121^{\circ} \mathrm{C}$ for 60 minutes. The sterile PDA prepared were distributed on sterilize petri dishes and were allowed to cool and solidify under aseptic conditions.

\subsection{Plant Material and Raising of Seedlings}

Seeds of tomato (Raiogrande) locally called iron tomato was obtained from the Farmer's Pharmacy in Bambili, North West Region of Cameroon.

The standard method of raising seedlings recommended by the Melkassa Agricultural Research Center (MARC) was used [21]. Seedlings were raised in 30 polythene bags $5 \mathrm{~cm}$ width and $10 \mathrm{~cm}$ length and height of plastic bags filled with soil was $10 \mathrm{~cm}$ for each bag. 
These bags were filled with soil mixed with fowl drops and sand and mixed uniformly. Grass mulch was applied on each bag and removed after the seedlings emerged. Watering of the bags was done twice a day to facilitate the decomposition of the fowl drops in order to reduce its acidity. On the $3^{\text {rd }}$ day the seeds were introduced into the soil $0.5 \mathrm{~cm}$. The seedlings in the bags were arranged using a complete block design method in five groups with each group having 6 bags of seedlings.

\subsection{Reactivation and Multiplication of Rhizopus spp}

Phosphate solubilizing fungus, Rhizopus spp (obtained from soya bean rhizosphere) was obtained from the Laboratory of Biology, Department of Biology HTTC, The University of Bamenda. Reactivation and multiplication of Rhizopus spp was done following the Murali standard method [22]. PDA media were prepared and autoclave at $121^{\circ} \mathrm{C}$ for one hour. For the inoculation process, $5 \mathrm{ml}$ of the aliquot containing the fungus was transferred and placed on Petri dishes containing on average $20 \mathrm{~mL}$ of PDA for spore growth under aseptic conditions. The Petri dishes were incubated for three days at $27^{\circ} \mathrm{C}$. After three days, the mycelium was then scraped from the Petri dishes with the help of sterile material and fungus spore solution was prepared by adding $20 \mathrm{~mL}$ of sterile distilled water in a bottle containing PDA broth for multiplication and incubated for seven days at $27^{\circ} \mathrm{C}$. After multiplication, the number of spores of Rhizopus $s p p$ was counted with the help of a Neubauer chamber using a light microscope giving counts of $1.0 \times 10^{5}$ spores $/ \mathrm{mL}^{-1}$ which was used to prepare the different concentration of Rhizopus spp used in the field.

\subsection{Grouping of Seedlings and Treatment with Rhizopus spp}

The seedlings were arranged using a complete block design method in five groups with each group having 6 bags of seedlings. Group I was the control, Groups II, to V treated with different concentration of Rhizopus spp 2.5; 5.0; 7.5 and $10.0 \mathrm{mg} / \mathrm{ml}$ respectively for 25 days by spraying. Growth parameters (number of leaves and height of plants) were recorded every 5 days up to 25 days, chlorophyll quantification was done. After 25 days, samples were collected for biochemical analysis (Flavonoids, phenol contents, total protein, vitamin $\mathrm{C}$, reduced $\mathrm{GHS}$ and CAT activity). At the end of experiment one, the best result was then used for phase two.

\subsection{Fungal Pathogen Culture}

Strain of Phytophthora infestans (gotten from infected potato tubes) was obtained from the Laboratory of Biology. Reactivation and multiplication of pathogenic fungal were done following Mbouobda method [20]. $5 \mathrm{ml}$ of obtained fungus was transferred into a petri dish containing PDA under aseptic condition and allowed to grow at $27 \pm 1^{\circ} \mathrm{C}$ for 48 hours in an incubator under a shaker. After 2 weeks, a sporangial suspension was prepared by scraping the surfaces of the colonies with a sterile scalpel, and the mycelia were suspended in sterilized water containing potato extract and dextrose (PD) to produce the infecting solution. The concentration of sporangia in the suspension was adjusted to $1.0 \times 10^{5}$ sporangia $\mathrm{ml}^{-1}$ using a Neubauer chamber with the help of a light microscope.

\subsection{In vitro Evaluation of Rhizopus spp on Pathogen Growth}

Rhizopus spp was screened under in vitro condition against $P$. infestans following dual culture technique [20]. Culture disc of $5 \mathrm{~mm}$ diameter each of the fungus antagonist and the pathogen were cut with the help of a sterilized laboratory knife and forcep from the margin of the actively growing culture and transferred to PDA in petri plates (90 $\mathrm{mm}$ diameter) on opposite sides approximately at $10 \mathrm{~mm}$ from the periphery of the plate. A control having the test pathogen only was also kept for comparison. The petri plates were then incubated at $27 \pm 1^{\circ} \mathrm{C}$ till the control plates were comparatively covered fully by the pathogen. This was further evaluated under field conditions for its antagonistic effect.

\subsection{Pathogen Inoculation and Disease Evaluation}

Four weeks old plants were divided into four groups with each group having six plants each. Group 1 consisted of plants $(\mathrm{H})$ without any treatment; group 2 of plants inoculated with $P$. infestans (I); group 3 of plants stimulated with Rhizopus spp (St) and group 4 of plants inoculated with $P$. infestans after stimulation with Rhizopus spp $(\mathrm{St}+\mathrm{I})$. Stimulation of plants was done 7 days before inoculation. It consisted of spraying of leaves with a solution of $5 \mathrm{mg} / \mathrm{ml}$ of 
Rhizopus spp. To cause infection, $50 \mathrm{ml}$ of infected solution containing the pathogen was spray on the plants of interest. At days 0, 2, 4, 6, 8 , and 10 , leaves of each group of plants were carefully examined in order to evaluate damages and recorded in terms of disease incidence and disease severity.

\subsection{Evaluation of Disease Incidence and Disease Severity}

Disease incidence was evaluated as percentage of altered leaves (i.e., those with symptoms) and disease severity as the area or volume of plant tissue that is visible and is relative to the total plant tissue. Plants were rated for disease incidence (DI) and disease severity (DS). DI as the presence or absence of disease (percentage of infected leaves on the plant) and DS as the severity percentage of disease damage. Severity of symptoms on individual plants was rated on a scale from 0 to 4 according to the percentage of foliage with yellowing or necrosis in acropetal progression: $0=0 \%, 1=1$ to $33 \%, 2=34$ to $66 \%, 3=67$ to $100 \%$ and $4=$ dead plant [21] .

Disease incidence (\%)

$=$ Number of infected plant units $\times 100$

Total number of units assessed

Disease severity $(\%)=n \times v / 4 N \times 100$

Where, $(n)=$ Number of plants in each category (v) = Numerical values of symptoms category, (N) = Total number of plants, (4) = Maximum numerical value of symptom category.

\subsection{Biochemical Analysis}

\subsubsection{Evaluation of chlorophyll content}

The chlorophyll content was estimated [23] and for each group, $0.5 \mathrm{~g}$ of fresh leaf sample was dipped in a well labelled test tubes containing $80 \%$ (V/V) acetone (Sigma-Aldrich). The test tubes containing the samples were sealed and kept in a dark corner for 48 hours at room temperature to extract all the chlorophyll. After 48 hours, the solutions were transferred to a cuvette and the optical density was measured at 645 and $663 \mathrm{~nm}$, against an $80 \%$ acetone blank using UV-VIS spectrophotometer model 752N. The content of chlorophyll 'a' and chlorophyll 'b' and total chlorophyll were determined using the equation given below:

Chlorophyll 'a' $(\mu / \mathrm{g} / \mathrm{ml})=(12.7 \times$ O.D. at $663 \mathrm{~nm})$ $-(2.69 \times$ O.D. at $645 \mathrm{~nm})$
Chlorophyll 'b' $(\mu / \mathrm{g} / \mathrm{ml})=(22.9 \times$ O.D. at $645 \mathrm{~nm})$ - $(4.08 \times$ O.D. at $663 \mathrm{~nm})$

Total chlorophyll $(\mu / \mathrm{g} / \mathrm{ml})=(20.2 \times$ O.D. at 645 $\mathrm{nm})+(8.02 \times$ O.D. at $663 \mathrm{~nm})$

The chlorophyll content was expressed as $\mathrm{mg}$ chlorophyll per gram of fresh leaf weight.

\subsubsection{Analysis of phenol and flavonoid contents}

The extraction for the analysis of total phenolic and flavonoid contents [24]. Extraction was done by dissolving $0.5 \mathrm{~g}$ of grind fresh plant leaves in 5 $\mathrm{ml}$ of 95\% methanol (Sigma-Aldrich), covered and kept in a dark corner for 48 hours. After which, they were centrifuged (4000 rpm, $10 \mathrm{~min}$ at $25^{\circ} \mathrm{C}$ ) and supernatant was collected and kept at $4^{\circ} \mathrm{C}$ for subsequent analysis.

Phenol analysis was done [25] using gallic acid as the standard. Phenols present in the plant react with phosphomolybdic acid in Folinciocalteau reagent in alkaline medium to produce a blue coloured complex (molybdenum blue) which absorbs light at $650 \mathrm{~nm}$ wavelength. The total phenolic contents in each sample were expressed as garlic acid equivalent in $\mu \mathrm{g} / \mathrm{g}$ of sample ( $\mu \mathrm{g} \mathrm{GAE/g}$ of plant).

Total flavonoid content was determined in the supernatant by the aluminium chloride colorimetric assay [26] using quercetin (SigmaAldrich) as the standard. Total flavonoid content in each sample were expressed as quercetin equivalent in $\mu \mathrm{g} / \mathrm{g}$ of sample ( $\mu \mathrm{g} \mathrm{QE} / \mathrm{g}$ of plant).

\subsubsection{Determination of Vitamin C}

Vitamin C concentration in plant leaves were quantified using redox titration method [27]. This method determines the vitamin $\mathrm{C}$ concentration in a solution using iodine. $1 \mathrm{~g}$ of fresh grind leaves was macerated in $10 \mathrm{ml}$ of distilled water. The mixture was then filtered with a filter paper Whatman Number 1. Five millilitres $(5 \mathrm{ml})$ of the filtrate was collected into a $250 \mathrm{ml}$ conical flask and into it $37.5 \mathrm{ml}$ of distilled water was added followed by $1 \mathrm{ml}$ of starch solution. The solution was titrated against with $0.005 \mathrm{~mole} / \mathrm{L}$ iodine solution and the endpoint was identified by the first permanent trace of a dark blue-black colour due to the formation of a starch-iodine complex. This was done for all the samples.

\subsubsection{Estimation of total protein}

Total protein content was determined [28] using BSA (Sigma-Aldrich) as the standard. The 
homogenate $(0.2 \mathrm{ml})$ of each sample was introduced into the individual assay tube, followed by $1.8 \mathrm{ml}$ of phosphate buffer $\mathrm{pH} 7.2$ $(0.1 \mathrm{M})$ and $2 \mathrm{ml}$ of biuret reagent. After $30 \mathrm{~min}$ of incubation at room temperature, the absorbance was read at $540 \mathrm{~nm}$ against a blank $(2 \mathrm{ml}$ of phosphate buffer $\mathrm{pH} 7.2,0.1 \mathrm{M}$ and $2 \mathrm{ml}$ of biuret reagent) using a UV-VIS spectrophotometer (model $752 \mathrm{~N}$ ). The intensity of colored complex formed is proportional to the protein concentration in the solution.

\subsubsection{Evaluation of antioxidants}

\subsubsection{Reduced glutathione level}

Reduced glutathione level was determined in the supernatant [29]. Twenty microliters of different group of plant homogenates were introduced into test tubes, followed by $3 \mathrm{ml}$ of Ellman's reagent. After homogenization, the tubes were incubated at room temperature for one hour. The Ellman reagent (Dithio-2, 2-dithio-5, 5`-dibenzoic acid (DTNB)) reacts with the $\mathrm{SH}$ groups of the glutathione to form a yellow coloured complex which absorbs at $412 \mathrm{~nm}$. The amount of cellular glutathione was expressed in mmole/mg of protein.

\subsubsection{Catalase activity}

Catalase activity was determined in the supernatant [30]. Three hundred microliters (300 $\mu \mathrm{l})$ of $9 \% \mathrm{H}_{2} \mathrm{O}_{2}$ (Sigma-Aldrich) were introduced into the cuvettes followed by $1400 \mu \mathrm{l}$ of the test samples while $1700 \mu \mathrm{l}$ of phosphate buffer $(0.1 \mathrm{M}, \mathrm{pH} 7.2)$ were introduced for the blank test. Three hundred microliters $(300 \mu \mathrm{l})$ fresh leave homogenate were then added into the test vessels and homogenized. After homogenization, the ODs were read at $240 \mathrm{~nm}$ at $0,30,60$ and 90 seconds. At $240 \mathrm{~nm}$, the absorbance of under graded hydrogen peroxide is directly proportional to the catalase concentration of the sample. The enzymatic activity of catalase was expressed in IU/mg of leave protein.

\section{RESULTS AND DISCUSSION}

\subsection{Results}

\subsubsection{Variation of number of leaves and height of tomato plants per treatment with Rhizopus spp}

The variation of the number of leaves of tomato plants treated with different concentrations of
Rhizopus spp for 25 days showed a progressive increase in the number of leaves in both experimental and control groups. There was a significant difference $(p<0.05)$ in the number of leaves of the plants treated with Rhizopus spp $(5.0 \mathrm{mg} / \mathrm{ml})$ when compared to the control group throughout the treatment period. In the other experimental groups, there was an increase in number of leaves but either slight or no significant difference when compared to the control group (Table 1).

There was a gradual increase in the plant height in both experimental and control groups as from day 5 . There was a significant difference $(p<$ 0.05 ) in the height of the plants treated with Rhizopus spp when compared to the control group, with Rhizopus spp $(5.0 \mathrm{mg} / \mathrm{ml})$ producing the tallest plants. Significant differences in the height of plants treated with Rhizopus spp (10.0 $\mathrm{mg} / \mathrm{ml}$ ) when compared to the control group throughout the experiment were noticed (Table 1).

\subsubsection{Variation of chlorophyll contents in tomato plants per treatment with Rhizopus spp}

Chlorophyll a, b and total chlorophyll contents in all plants increased from day 5 to day 25 (Fig. 1). On day 0 , there was no significance difference in chlorophyll a in both the experimental groups and control one. On days 5, 10 and 15, there were significant differences in chlorophyll a content in plants treated with $5.0 \mathrm{mg} / \mathrm{ml}$ of Rhizopus spp when compared to the control while the other treated plant groups were slightly but not significantly different. After 20 days, plants treated with $2.5 \mathrm{mg} / \mathrm{ml}$ and $5.0 \mathrm{mg} / \mathrm{ml}$ of Rhizopus spp showed a significant increase in chlorophyll a content while after 25 days, there was a slight difference in chlorophyll a content but not significantly to the control group. With regards to chlorophyll $b$, no significant difference in chlorophyll b content was noticed on days 5 , 20 and 25 . There was a significant difference ( $p$ $<0.05$ ) in chlorophyll b content in plants treated with $5.0 \mathrm{mg} / \mathrm{ml}$ of Rhizopus spp compared to the control group while the other groups were significantly not different (Fig. 1).

Total chlorophyll content was significantly different between the experimental and control groups throughout the experiment except on day 15. 
Table 1. Variation of number of leaves and heights of tomato plants treated with Rhizopus spp

\begin{tabular}{|c|c|c|c|}
\hline Days & $\begin{array}{l}\text { Treatment (Rhizopus spp } \\
\mathrm{mg} / \mathrm{ml} \text { ) }\end{array}$ & Number of leaves & Plant height $(\mathrm{cm})$ \\
\hline \multirow[t]{5}{*}{0} & 0 & $2.0 \pm 0.0^{\mathrm{a}}$ & $2.75 \pm 0.92^{\mathrm{a}}$ \\
\hline & 2.5 & $2.0 \pm 0.0^{\mathrm{a}}$ & $2.55 \pm 0.15^{\mathrm{a}}$ \\
\hline & 5.0 & $2.0 \pm 0.0^{\mathrm{a}}$ & $2.53 \pm 0.22^{\mathrm{a}}$ \\
\hline & 7.5 & $2.0 \pm 0.0^{\mathrm{a}}$ & $2.57 \pm 0.17^{\mathrm{a}}$ \\
\hline & 10 & $2.0 \pm 0.0^{\mathrm{a}}$ & $2.75 \pm 0.09^{\mathrm{a}}$ \\
\hline \multirow[t]{5}{*}{5} & 0 & $3.33 \pm 0.21^{\mathrm{a}}$ & $4.33 \pm 0.35^{\mathrm{a}}$ \\
\hline & 2.5 & $3.50 \pm 0.22^{\mathrm{a}}$ & $4.50 \pm 0.18^{\mathrm{a}}$ \\
\hline & 5.0 & $3.83 \pm 0.17^{\mathrm{a}}$ & $4.95 \pm 0.33^{\mathrm{ab}}$ \\
\hline & 7.5 & $3.33 \pm 0.21^{\mathrm{a}}$ & $3.78 \pm 0.28^{\mathrm{a}}$ \\
\hline & 10 & $3.17 \pm 0.17^{\mathrm{a}}$ & $3.78 \pm 0.25^{\mathrm{a}}$ \\
\hline \multirow[t]{5}{*}{10} & 0 & $4.67 \pm 0.21^{\mathrm{ab}}$ & $6.47 \pm 0.21^{\mathrm{ab}}$ \\
\hline & 2.5 & $4.50 \pm 0.22^{\mathrm{ab}}$ & $6.85 \pm 0.26^{\mathrm{ab}}$ \\
\hline & 5.0 & $5.17 \pm 0.17^{\mathrm{a}}$ & $7.33 \pm 0.17^{\mathrm{a}}$ \\
\hline & 7.5 & $4.50 \pm 0.22^{\mathrm{ab}}$ & $6.15 \pm 0.26^{b}$ \\
\hline & 10 & $4.00 \pm 0.0^{\mathrm{b}}$ & $6.28 \pm 0.27^{b}$ \\
\hline \multirow[t]{5}{*}{15} & 0 & $5.33 \pm 0.21^{b}$ & $7.98 \pm 0.34^{\mathrm{ab}}$ \\
\hline & 2.5 & $5.67 \pm 0.21^{\mathrm{ab}}$ & $8.57 \pm 0.42^{\mathrm{ab}}$ \\
\hline & 5.0 & $6.17 \pm 0.17^{\mathrm{a}}$ & $9.27 \pm 0.22^{\mathrm{a}}$ \\
\hline & 7.5 & $5.50 \pm 0.22^{\mathrm{ab}}$ & $7.50 \pm 0.38^{\mathrm{b}}$ \\
\hline & 10 & $5.17 \pm 0.17^{\mathrm{b}}$ & $7.52 \pm 0.31^{\mathrm{b}}$ \\
\hline \multirow[t]{5}{*}{20} & 0 & $6.50 \pm 0.22^{\mathrm{bc}}$ & $9.37 \pm 0.47^{b}$ \\
\hline & 2.5 & $7.17 \pm 0.31^{\mathrm{ab}}$ & $11.27 \pm 0.60^{\mathrm{a}}$ \\
\hline & 5.0 & $7.83 \pm 0.17^{\mathrm{a}}$ & $12.82 \pm 0.56^{\mathrm{ab}}$ \\
\hline & 7.5 & $6.50 \pm 0.22^{\mathrm{bc}}$ & $10.75 \pm 0.43^{\mathrm{ab}}$ \\
\hline & 10 & $6.17 \pm 0.17^{c}$ & $10.32 \pm 0.40^{\mathrm{b}}$ \\
\hline \multirow[t]{5}{*}{25} & 0 & $7.83 \pm 0.17^{b}$ & $12.33 \pm 0.82^{\mathrm{d}}$ \\
\hline & 2.5 & $8.83 \pm 0.40^{\mathrm{ab}}$ & $16.08 \pm 0.75^{\mathrm{bc}}$ \\
\hline & 5.0 & $9.50 \pm 0.43^{\mathrm{a}}$ & $19.50 \pm 0.55^{\mathrm{a}}$ \\
\hline & 7.5 & $8.67 \pm 0.21^{\mathrm{ab}}$ & $16.83 \pm 0.62^{\mathrm{ab}}$ \\
\hline & 10 & $8.33 \pm 0.33^{\mathrm{ab}}$ & $13.67 \pm 0.88^{\mathrm{cd}}$ \\
\hline
\end{tabular}

\subsubsection{Effect of Rhizopus spp on tomato plants flavonoids, phenolic and vitamin C contents}

There was slight variation in the level of flavonoids in plants treated with Rhizopus spp $(2.5 \mathrm{mg} / \mathrm{ml}(106.46 \pm 10.56 \mu \mathrm{g} / \mathrm{g})$ and $10.0 \mathrm{mg} / \mathrm{ml}$ $(88.49 \pm 6.26 \mu \mathrm{g} / \mathrm{g})$ when compared to the control $(73.28 \pm 8.99 \mu \mathrm{g} / \mathrm{g})$. There was a significant difference $(p<0.05)$ in the level of phenols in plant treated with the different concentration of Rhizopus spp with Rhizopus spp $(5.0 \mathrm{mg} / \mathrm{ml})$ having the highest value $(79.82 \pm$ $0.795 \mu \mathrm{g} / \mathrm{g}$ ) compared to the control (36.54 \pm $3.97 \mu \mathrm{g} / \mathrm{g})$. No significant difference $(p>0.05)$ in the level of vitamin $C$ in the experimental groups compared to the control group was noticed (Table 2).

\subsubsection{Effect of Rhizopus spp on tomato plants total protein, GSH and CAT}

The evaluation of total protein, level of reduced glutathione (GHS) and of catalase activity (CAT) showed a significant decrease in the level of total protein $(p<0.05)$ in plants treated with $2.5 \mathrm{mg} / \mathrm{ml}$ of Rhizopus spp (0.076 $\pm 0.004 \mathrm{mg} / \mathrm{g})$ compared to the control $(0.118 \pm 0.004 \mathrm{mg} / \mathrm{g})$. The other experimental groups showed no significant differences in the level of total protein contents. Level of reduced GSH and catalase activity significantly increased $(p<0.05)$ in all group of plants treated with the different concentrations of Rhizopus spp with plants treated with $5.0 \mathrm{mg} / \mathrm{ml}$ of Rhizopus spp having the highest value when compared to the control group (Table 3). 
Chl a
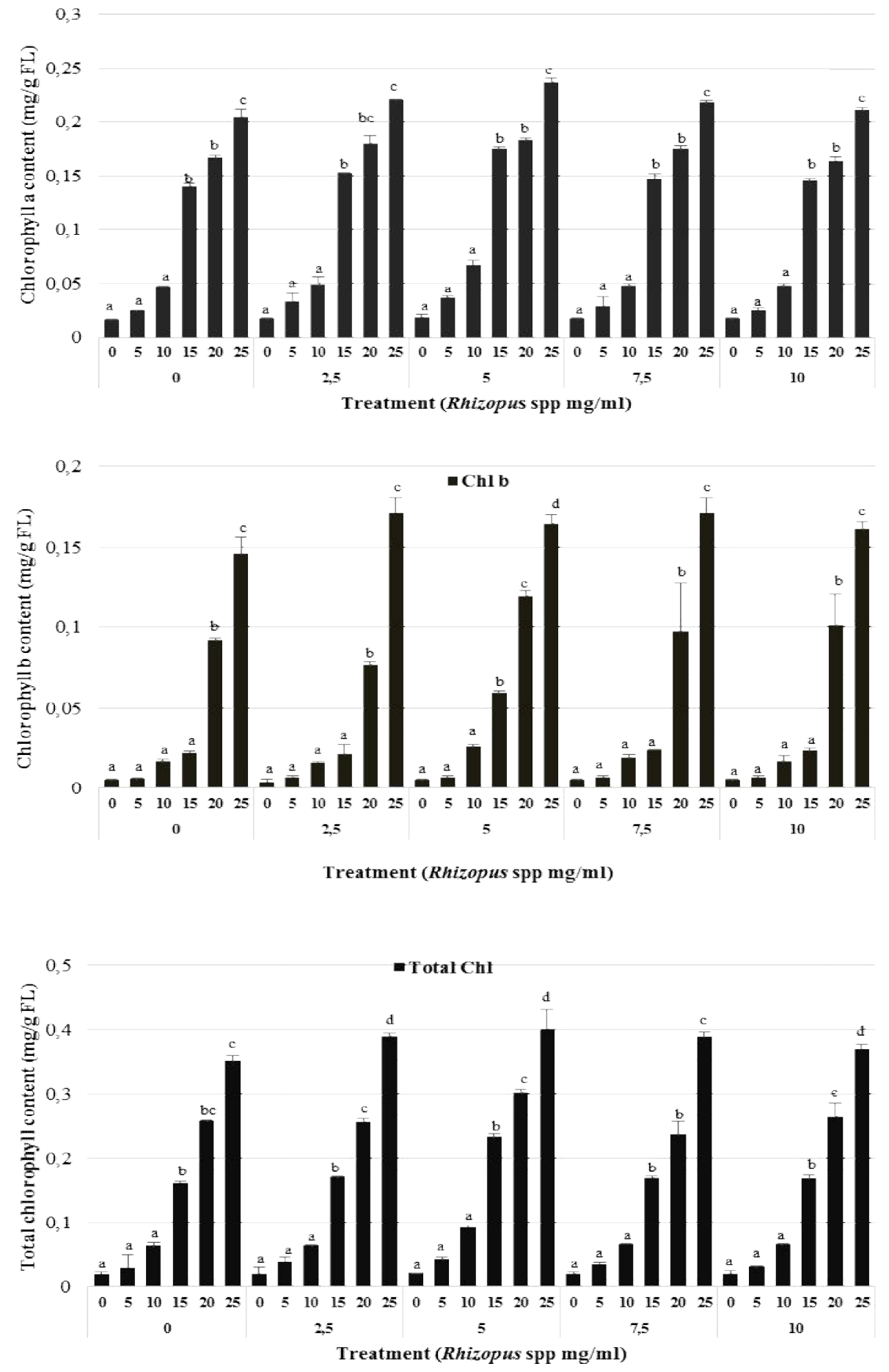

Fig. 1. Variation of $\mathrm{Chl} \mathrm{a,} \mathrm{Chl} \mathrm{b}$ and total $\mathrm{Chl}(\mathrm{a}+\mathrm{b})$ leaves content of tomato plants treated with Rhizopus spp for 25 days

Data not sharing a common letter for the same concentration are significantly different $(p<0.05)$ after one-way ANOVA and paired wise comparison using Tukey test 
Table 2. Level of flavonoids, total phenolic and vitamin C content in tomato plants treated with Rhizopus spp

\begin{tabular}{llll}
\hline $\begin{array}{l}\text { Treatments } \\
(\mathbf{m g} / \mathbf{m l})\end{array}$ & $\begin{array}{l}\text { Flavonoids } \\
(\boldsymbol{\mu g} / \mathbf{g} \text { of } \mathbf{F L})\end{array}$ & $\begin{array}{l}\text { Phenols } \\
(\boldsymbol{\mu g} / \mathbf{g} \text { of } \mathbf{F L})\end{array}$ & $\begin{array}{l}\text { Vitamin C } \\
(\mathbf{m g} / \mathbf{m l})\end{array}$ \\
\hline 0 & $73.28 \pm 8.99^{\mathrm{b}}$ & $36.54 \pm 3.97^{\mathrm{c}}$ & $0.0073 \pm 0.00035^{\mathrm{a}}$ \\
2.5 & $106.46 \pm 10.56^{\mathrm{ab}}$ & $60.15 \pm 0.795^{\mathrm{b}}$ & $0.0070 \pm 0.00014^{\mathrm{a}}$ \\
5 & $117.52 \pm 8.21^{\mathrm{a}}$ & $79.82 \pm 0.795^{\mathrm{a}}$ & $0.0074 \pm 0.00014^{\mathrm{a}}$ \\
7.5 & $109.50 \pm 8.60^{\mathrm{a}}$ & $41.88 \pm 2.78^{\mathrm{c}}$ & $0.0072 \pm 0.00021^{\mathrm{a}}$ \\
10 & $88.49 \pm 6.26^{\mathrm{ab}}$ & $52.56 \pm 1.99^{\mathrm{b}}$ & $0.0075 \pm 0.00042^{\mathrm{a}}$ \\
\hline
\end{tabular}

Data not sharing a common letter are significantly different $(p<0.05)$ after one-way ANOVA and paired wise comparison using Tukey test

Table 3. Level of total protein, reduced GSH and CAT in tomato plants treated with Rhizopus spp

\begin{tabular}{llll}
\hline $\begin{array}{l}\text { Treatments } \\
\text { (mg/ml) }\end{array}$ & $\begin{array}{l}\text { Total protein } \\
\text { ( } \mathbf{m g} / \mathbf{g} \text { of } \mathrm{FL}\end{array}$ & $\begin{array}{l}\text { GSH } \\
\text { (mmole/mg of protein) }\end{array}$ & $\begin{array}{l}\text { CAT } \\
\text { (IU/mg of leave protein) }\end{array}$ \\
\hline 0 & $0.118 \pm 0.004^{\mathrm{a}}$ & $1.63 \pm 0.25^{\mathrm{b}}$ & $1.93 \pm 0.03^{\mathrm{b}}$ \\
2.5 & $0.076 \pm 0.004^{\mathrm{b}}$ & $4.13 \pm 1.64^{\mathrm{a}}$ & $4.75 \pm 0.7^{\mathrm{a}}$ \\
5 & $0.119 \pm 0.003^{\mathrm{a}}$ & $4.10 \pm 0.46^{\mathrm{a}}$ & $5.24 \pm 0.20^{\mathrm{a}}$ \\
7.5 & $0.115 \pm 0.02^{\mathrm{a}}$ & $3.55 \pm 0.25^{\mathrm{a}}$ & $4.20 \pm 0.05^{\mathrm{a}}$ \\
10 & $0.108 \pm 0.007^{\mathrm{ab}}$ & $3.36 \pm 0.02^{\mathrm{a}}$ & $4.06 \pm 0.68^{\mathrm{a}}$ \\
\hline
\end{tabular}

Data not sharing a common letter are significantly different $(p<0.05)$ after one-way ANOVA and paired wise comparison using Tukey test

3.1.5 Evaluation of disease incidence and severity in tomato plants stimulated with Rhizopus spp and infected with $P$. Infestans

Disease incidence and disease severity of tomato plants stimulated with $5.0 \mathrm{mg} / \mathrm{ml}$ of Rhizopus spp and infected with $P$. infestans showed a slight significant increase in the percentage of disease incidence in plants treated with $P$. infestans $(52.8 \pm 0.39 \%)$ compared to the control (36.1 $\pm 0.25 \%)$. Co-administration of both Rhizopus spp and $P$. infestans significantly decrease the percentage of disease incidence. There was a slight significance increase $(p<$ 0.05 ) in the percentage of disease severity in plants stimulated with $P$. infestans (13.54 \pm $0.03 \%$ ) while co-administration of Rhizopus spp and $P$. infestans significantly decrease the percentage of disease severity when compared to the control groups (Table 4).

\subsubsection{Effect of Rhizopus spp stimulation and $P$. infestans infection on tomato plants total protein, GSH and CAT content}

There was a slight significant decrease in the level of total protein in plants treated with $P$. infestans $(0.138 \pm 0.01 \mathrm{mg} / \mathrm{g})$ when compared to the control $(0.161 \pm 0.004 \mathrm{mg} / \mathrm{g})$. Co-inoculation of tomato plants with Rhizopus spp and $P$. infestans significantly increased $(p<0.05)$ plant total protein content $(0.185 \pm 0.006 \mathrm{mg} / \mathrm{g})$ compared to the control. Based on the level of reduced GSH and CAT activity, there was a significant decrease in the antioxidants (GSH and CAT) in plants treated with $P$. infestans compared to the control. Co-administration of tomato plants with Rhizopus spp and $P$. infestans significantly increased $(p<0.05)$ plant antioxidants level (reduced GSH and CAT activity) compared to the control (Table 5).

\subsection{Discussion}

In the coming decades, increased focus would be on harmless and environmentally friendly techniques, such as the use of beneficial microorganisms in sustainable crop production [31]. Large numbers of beneficial rhizospheric fungi (especially PSF) have previously been investigated, with the goal of identifying microorganisms that have the ability to enhance host plant vigour and performance while inducing resistance against diseases. This study investigated growth parameters, photosynthetic activity and enzymatic activities, flavonoids, phenolic, total protein, vitamin $\mathrm{C}$ contents and non-enzymatic level upon application of Rhizopus spp on tomato leaves with or without infection of $P$. infestans. 
Table 4. Disease incidence and severity in tomato plants stimulated with Rhizopus spp (5.0 $\mathrm{mg} / \mathrm{ml}$ ) and infected with $P$. Infestans

\begin{tabular}{lll}
\hline Treatments $(5.0 \mathrm{mg} / \mathrm{ml})$ & Disease incidence $(\%) \pm$ SD & Disease severity (\%) \pm SD \\
\hline Control & $36.1 \pm 0.25^{\mathrm{ab}}$ & $10.42 \pm 0.06^{\mathrm{ab}}$ \\
Rhizopus spp & $8.33 \pm 0.09^{\mathrm{b}}$ & $3.13 \pm 0.03^{\mathrm{b}}$ \\
P. infestans & $52.8 \pm 0.39^{\mathrm{a}}$ & $13.54 \pm 0.03^{\mathrm{a}}$ \\
Rhizopus + P. infestans & $11.12 \pm 0.07^{\mathrm{b}}$ & $4.17 \pm 0.09^{\mathrm{ab}}$ \\
\hline
\end{tabular}

Data not sharing a common letter are significantly different $(p<0.05)$ after one-way ANOVA and paired wise comparison using Tukey test

Table 5. Level of plant total protein, reduced GSH and CAT activity in tomato plants treated with Rhizopus spp $(5.0 \mathrm{mg} / \mathrm{ml})$ and $P$. Infestans

\begin{tabular}{|c|c|c|c|}
\hline Treatments $(5.0 \mathrm{mg} / \mathrm{ml})$ & $\begin{array}{l}\text { Total protein } \\
\text { (mg/g of } F L)\end{array}$ & $\begin{array}{l}\text { GSH (mmole/mg of } \\
\text { protein) }\end{array}$ & $\begin{array}{l}\text { CAT } \\
\text { (IU/mg protein) }\end{array}$ \\
\hline Control & $0.161 \pm 0.004^{\text {ab }}$ & $3.78 \pm 0.10^{\mathrm{ab}}$ & $2.91 \pm 0.2^{\mathrm{bc}}$ \\
\hline Rhizopus spp & $0.185 \pm 0.001^{\mathrm{a}}$ & $4.53 \pm 0.30^{\mathrm{a}}$ & $4.10 \pm 0.04^{b}$ \\
\hline P. infestans & $0.138 \pm 0.01^{\mathrm{b}}$ & $1.95 \pm 0.54^{b}$ & $1.85 \pm 0.23^{\mathrm{c}}$ \\
\hline Rhizopus $+P$. infestans & $0.185 \pm 0.006^{\mathrm{a}}$ & $6.15 \pm 0.01^{\mathrm{a}}$ & $6.83 \pm 0.61^{a}$ \\
\hline
\end{tabular}

Phosphorus deficiency in soil is an important limiting factor in global crop production. Some microorganisms can increase the concentration of available $P$ by secreting organic acids and various degrading enzymes (phytase, nuclease, phosphatase, etc.) to decompose insoluble phosphate in the soil but these microorganisms release little $P$ in their natural state [32]. Therefore, it is necessary to artificially inoculate some high-efficiency $P$ solubilizing microorganisms to increase the amount of available $P$. The results of the present study showed that the single inoculation of Rhizopus spp had positive effects on the growth, photosynthetic capacity, total protein, flavonoids, phenols and antioxidants content in the leaves of tomato plants while protecting the plant against late diseases such as late blight.

Inoculation of Rhizopus spp increased the plant height and number of leaves of tomato plant when compared to the control. This might be due to the ability of Rhizopus spp dissolving the insoluble phosphate in the soil and enhancing the available $\mathrm{P}$ content by producing organic acid and extracellular phosphatases. PSF both singly or in combination gave maximum number of leaves and height on maize plants due to the activity of $P$ solubilization and released growthpromoting substances [33].

Plants used light energy absorbed by chlorophyll molecules to drive photosynthesis [32].
Photosynthesis is a primary physiological process to enhance plant's life through the use of light energy and synthesis of organic compounds in plants and the efficiency of photosynthesis relies on content of chlorophyll [11]. Results obtained showed that application of Rhizopus $s p p$ increased the amount of Chlorophyll $a, b$ and total chlorophyll contents when compared to the control as per treatment days with plants treated with Rhizopus spp $(5 \mathrm{mg} / \mathrm{ml})$ having the highest chlorophyll content. This result suggests that Rhizopus spp have a protective effect on chlorophyll against pathogen in tomato leaves. These results are in line with those obtained by Elais [33] who found that the integrated treatment of P-solubilizers and application of rock-P significantly led to large number and area of leaves as well as the photosynthetic pigments in tomato plants and also Ferus and Arkosiova [34] of plants under fluctuating environment.

Among several common metabolites, phenolics and flavonoid compounds have protective activity with free radicals and antiseptic properties in plants hence they are produced by plants to defend them against pathogens attack [11]. Phenolic and flavonoid molecules are important antioxidant components which are responsible for deactivating free radicals based on their ability to donate hydrogen atoms to free radicals. Different literature reports also have ideal structural characteristics for free radical scavenging reports and indicate a linear 
correlation of total phenolic and flavonoid content with antioxidant capacity [35]. Result exhibited a significant increase in phenolics contents in tomato leaves treated with Rhizopus spp. Total concentration of flavonoids in tomato leaves were increased in Rhizopus spp treated samples. Rhizopus might have the ability to stimulate or produce secondary metabolites such as flavonoids and phenols which help plants to fight against stress factors such as disease caused by pathogens. PSFs have the ability to produced secondary metabolites such as defensive enzymes and non-antioxidants such as flavonoids, phenols, vitamin $C$ to combat plant diseases as a result of free radicals [36]. Rhizopus spp like any other PSFs have the ability to produced antioxidants. Trichoderma asperellum, one of the PSFs has the capacity to produced antioxidants which help plant to counteract the reactive oxygen species (ROS) produced by Fusarium oxysporum and Botrytis cinerea causing tomato diseases [12].

There was an increase in disease incidence and disease severity in plants inoculated with $P$. infestans alone when compared to the control. Less disease incidence and severity were recorded in Rhizopus spp inoculated plants than in untreated plants. This shows that Rhizopus spp have the ability to stimulate and enhanced mechanisms involved against pathogens attack such the production of defensive enzymes, flavonoids and phenols. Plants are able to defend themselves upon numerous phytopathogens attacks by producing a wide spectrum of defence. Plant antioxidant defenses, oxidative enzymes productions, have expanded with aerobic alteration to balance oxidative damage caused by ROS. Protective enzymes included catalase (CAT), ascorbate peroxidase (APx) and superoxide dismutase (SOD), and various molecules including glutathione, proline, ascorbate and carotenoid. Changes in activity of ROS scavenging enzymes can also be a crucial step in activating plant defense against plant pathogens [11]. The activity of the antioxidant enzyme system has been noted to limit the release of oxidative proteins and enable cells to resist the inoculation of $P$. infestans in plant cells. In this study, GSH level and CAT activity significantly decrease $(p<0.05)$ in plants treated with $P$. infestans alone when compared to the control group while significantly increase tomato leaves pre-treated with Rhizopus spp after infection with $P$. infestans. It is suggested that Rhizopus spp have the capacity to produced GSH and CAT upon attacked by a pathogen like any other PSFs. PSF have the ability to produced antioxidants when inoculated in plants and act as the earliest line of defense against oxidative stress initiated by pathogens [12].

\section{CONCLUSION}

Tomato is one of the most important vegetable crop in Cameroon especially in the North West Region. Diseases are major constraints that limit production of tomato in the country. Late blight is a very severe disease in most tomato growing regions, including the North West Region, where information on disease management options through biocontrol agents are still inadequate. The results of this study provide evidence that diverse groups of fungi isolated form soil rhizosphere such as phosphate solubilizing fungi have the ability to promote growth that is acting as bio fertilizers and inducing host resistance (biopesticides). Based on growth promotion an increase in growth parameters and chlorophyll contents while stimulating the production of flavonoids, phenols, GSH and CAT which act as defense system against pathogen attacks. Rhizopus spp therefore instigate plant growth and induce disease resistance in tomato upon infection with $P$. infestans causing late blight.

\section{COMPETING INTERESTS}

Authors have declared that no competing interests exist.

\section{REFERENCES}

1. Ballester AR, Tikunov $Y$, Molthoff J, Grandillo S, Viquez Zamora M, De Vos R, et al. Identification of loci affecting accumulation of secondary metabolites in tomato fruit of a Solanum lycopersicum. Front. Plant Science. 2016; 7:1-14.

2. Getachew GM. Integrated management of tomato late blight [Phytophthora infestans (mont.) de bary] through host plant resistance and reduced frequency of fungicide application in Gamo Gofa zone, Southern Ethiopia. M.Sc. Thesis, Haramaya University, Haramaya, Ethiopia; 2017

3. Chapei S, Pongener N, Kangjam V. Integrated management of early blight of tomato (Lycopersicon esculentum Mill.) caused by Alternaria solani (Ellis and Martin) Jones and Grout. International Journal of Current Microbiology and Applied Sciences. 2019;8(5):2428-2436. ISSN: 2319-7706. 
Available:https://doi.org/10.20546/ijcmas.2 019.805.287.

4. Garcia PG, Dos Santos FN, Zanotta S, Eberlin MN, Carazzone C. Metabolomics of Solanum lycopersicum Infected with Phytophthora infestans leads to early detection of late blight in asymptomatic plants. Molecules. 2018;23:3330;

DOI: $10.3390 /$ molecules23123330.

Available:www.mdpi.com/journal/molecule $\mathrm{s}$

5. Meya IA, Mamiro PD, Kusolwa MP, Maerere PA, Sibuga KP, Erbaugh $M$, et al. Management of tomato late blight disease using reduced fungicide spray regimes in Morogoro, Tanzania. Tanzania Journal of Agricultural Sciences. 2014; 13(2):8-17.

6. Fontem AD. Quantitative effects of early and late blights on tomato yields in Cameroon. Tropicultura. 2003; 21(1):3641.

7. Majeeb A, Muhammad Z, Ullah Z, Ullah R, Ahmad $H$. Late blight of potato (Phytophthora infestans) I: Fungicides application and associated challenges. Turkish Journal of Agriculture-Food Science and Technology. 2017;5(3):261266.

8. Sudisha J, Mostafa A, Lam Son PT, Shin ichi Ito. Characterization of rhizosphere fungi that mediate resistance in tomato against bacterial wilt disease. Journal of Experimental Botany. 2013;64(12):38293842.

9. Judelson HS, Blanco FA. The spores of Phytophthora: weapons of the plant destroyer. Nature Reviews Microbiology. 2005; 3:47-58.

10. Dahlin P. Analysis of sterol metabolism in the pathogenic oomycetes Saprolegnia parasitica and Phytophthora infestans. Thesis; 2016. ORCID iD: 0000-0002-9945-8059.

11. Mohammadi AM, Han X, Zhang Z, Xi Y, Boorboori M, Wang Pruski G. Phosphite application alleviates Pythophthora infestans by modulation of photosynthetic and physio-biochemical metabolites in potato leaves. Pathogens. 2020;9:170-179

12. Herrera Téllez IV, Cruz Olmedo A, Plasencia J, Gavilanes Ruíz M, Arce Cervantes $\mathrm{O}$, Hernández León $\mathrm{S}$, et al. The protective effect of Trichoderma asperellum on tomato plants against Fusarium oxysporum and Botrytis cinerea diseases involves inhibition of reactive oxygen species production. International Journal of Molecular Sciences; 2017. DOI: $\quad 10.3390 /$ ijms20082007 Available:www.mdpi.com/journal/ijms

13. Shoresh M, Mastouri F, Harman GE. Induced systemic resistance and plant responses to fungal biocontrol agents. Annual Review of Phytopathology. 2010; 48:21-43

14. Rubin RL, Groonigen KJV, Hungate BA. Plant growth promoting rhizobacteria are more effective under drought: a metaanalysis. Plant Soil; 2017.

DOI: $10.1007 / \mathrm{s} 11040-017-3199-8$

15. Hashem A, Abdulaziz AC, Ramalingam R, Al Bandari FA, Aldehaish $\mathrm{HA}$, Egamberdieva D, et al. Arbuscular mycorrhizal fungi regulate the oxidative system, hormones and ionic equilibrium to trigger salt stress tolerance in Cucumis sativus L. Saudi Journal of Biological Sciences. 2018;25:1102-1114

16. Malviya J, Singh K, Joshi V. Effect of phosphate solubilizing fungi on growth and nutrient uptake of ground nut (Arachis hypogaea) plants. Advances in Bioresearch. 2011; 2(2):110-113.

17. Alam SS, Sakamoto K, Inubushi K. Effect of Penicillium sp. EU0013 inoculation on tomato growth and Fusarium wilt. Horticultural Research. 2011;65:69-73

18. Murali M, Thriveni MC, Manjula S, Mythrashree SR, Amruthesh KN. Isolation of phosphate solubilizing fungi from rhizosphere soil and its effect on seed growth parameters of different crop plants. Journal of Applied Biology \& Biotechnology. 2016; 4 (06):022-026.

19. Gryganskyi PA, Golan J, Stajich EJ. Phylogenetic and phylogenomic definition of Rhizopus species. Genetic Society of America. 2019;9(8):2789-2793.

20. Mbouobda HD, Muyang RF, Djeuani AC, Djou TI, Fotso. In vitro characterisation of endophytic fungi strains from Lantana camara leaves displaying antifungal activity against Phytophthora colocasiae. Journal of Diseases and Medicinal Plants. 2019;5(6):87-95

21. Getachew G, Tesfaye A, Kassahun T. Evaluation of disease incidence and severity and yield loss of finger millet varieties and mycelia growth inhibition of Pyricularia grisea isolates using biological antagonists and fungicides in vitro 
condition. Journal of Applied Biosciences. 2014;73: 5883- 5901.

ISSN: 1997-5902

22. Murali M, Thriveni MC, Manjula S, Mythrashree SR, Amruthesh KN. Isolation of phosphate solubilizing fungi from rhizosphere soil and its effect on seed growth parameters of different crop plants. Journal of Applied Biology and Biotechnology. 2016;4(06):022-026.

23. Arnon DI. Copper enzyme polypheno loxides in isolated chloroplast in Beta vulgaris. Plant Physiology. 1949; 24 : 1-15.

24. Naczk M, Shahidi F. Extraction and analysis of phenolics in food. Journal of Chromatography A. 2004; 1054(1-2):95111.

25. Khoddami A, Wilkes AM, Roberts HT. Techniques for analysis of plant phenolic compounds. Molecules. 2013;18:23282375

26. Kamtekar S, Keer V, Patil V. Estimation of phenolic content, flavonoid content, antioxidant and alpha amylase inhibitory activity of marketed polyherbal formulation. Journal of Applied Pharmaceutical Science. 2014; 4(09):061-065.

27. Helmenstine MA. Vitamin C determination by iodine titration; 2019.

28. Gornall AG, Bardawill CJ, David MM. Determination of serum proteins by means of the biuret reaction. Journal of Biological Chemistry. 1949;177:751-766

29. Ellman GL. Tissue sulphydryl groups. Archives of Biochemistry and Biophysics. 1959;82(1):70-77.

30. Misra H, Fridovich I. The role of superoxide anion in the autoxidation of epinephrine and a simple assay for superoxide dismutase. The Journal of Biological Chemistry. 1972; 247(10):3170-3175.

PMID: 4623845
31. Lubna Asaf $\mathrm{S}$, Hamayun $\mathrm{M}$, Gul $\mathrm{H}$, In Jung Lee, Hussain A. Aspergillus niger CSR3 regulates plant endogenous hormones and secondary metabolites by producing gibberellins and indoleacetic acid. Journal of Plant Interactions. 2018;17429145.

32. Wu F, Li J, Chen Y, Zhang L, Zhang Y, Wang $S$, et al. Effects of phosphate solubilizing bacteria on the growth, photosynthesis, and nutrient uptake of Camellia oleifera Abel. Forests. 2019; 10:348-353

33. Elias F, Muleta D, Woyessa D. Effects of phosphate solubilizing fungi on growth and yield of haricot bean (Phaseolus vulgaris L.) plants. Journal of Agricultural Science. 2016;8(10):1916-9752:

Available:http://dx.doi.org/10.5539/jas.v8n 10p204

34. Ferus $\mathrm{P}$, Arkosiova $\mathrm{M}$. Variability of chlorophyll content under fluctuating environment. Acta Fytotechnica et Zootechnica (In: Proceedings of the International Scientific Conference on the occasion of the 55th Anniversary of the Slovak Agricultural University in Nitra 123). 2001;4.

35. Aryal S, Baniya KM, Danekhu K, Kunwar P, Gurung R, Koirala N. Total phenolic content, flavonoid content and antioxidant potential of wild vegetables from Western Nepal plants. Plants. 2019;8;96.

DOI: $10.3390 /$ plants 8040096

36. Naziya B, Murali M, Amruthesh NK. Plant growth-promoting fungi (PGPF) instigate plant growth and induce disease resistance in Capsicum annuum L. upon Infection with Colletotrichum capsici (Syd.) Butler \& Bisby. Biomolecules. 2020;10;4148.

(c) 2021 Agbor et al.; This is an Open Access article distributed under the terms of the Creative Commons Attribution License (http://creativecommons.org/licenses/by/4.0), which permits unrestricted use, distribution, and reproduction in any medium, provided the original work is properly cited.

The peer review history for this paper can be accessed here: http://www.sdiarticle4.com/review-history/65585 